\title{
Parametric Studies of Floor Rotation Performance of Assymmetrical Building Affected by Pulse Ground Motion
}

\author{
Ade Faisal ${ }^{1}$, Gamal Halim ${ }^{2}$ \\ \{adefaisal@yahoo.com ${ }^{1}$, gamalhalim@live.com ${ }^{2}$ \} \\ ${ }^{1}$ Universitas Muhammadiyah Sumatera Utara, Medan, Indonesia \\ ${ }^{2}$ Universitas Sumatera Utara, Medan, Indonesia
}

\begin{abstract}
Earthquake resistant building must be designed with a proper plan configuration. Although the regular and symmetrical building plans have been known to have a good behaviour under earthquake loads, the facts have demonstrated that many asymmetrical plan buildings are built for the architectural reasons. Irregular plan buildings cause mass distribution, stiffness, and strength asymmetries which in turn produce the eccentricity to the centre of mass. In this research, the asymmetrical buildings are simulated under earthquake ground motion containing pulse. The study aims to evaluate the drift and floor rotations that occur in the asymmetrical buildings. The results indicate that the difference in drift of symmetrical and asymmetrical building reach $8 \%$ to $20 \%$. The rotation occurred on the rigid side (high stiffness side) is smaller than the flexible side (low stiffness side). The difference in eccentricity affects clearly the inelastic floor rotation.
\end{abstract}

Keywords: Eccentricity Stiffness, Pulse Ground Motion, Floor Rotation.

\section{Introduction}

The damage of building can be avoided by understandingproperly the configuration plan of building. Although the symmetricalplan buildings have been known to have better behavior under earthquake action, many developer have built their multi-story building in assymmetrical plan configuration. This is done for the sake of esthetical view of point.

Irregular shape plan buildings (so-called assymmetrical building), like most buildings in general, can cause severe damage to structures when exposed to seismic forces. Assymmetrical buildings cause mass distribution, stiffness and strength are not at the sama point. This conditionproducesthe eccentricity to the center of mass and causes the floor rotation movement during an earthquake. Floor torsion can cause quite serious problems in buildings such as increased displacement at the extreme points of the building and the problems in lateral retaining elements located on the edges of buildings. Floor rotation can not be eliminated but its value can be minimized and hence it would reduce the damage risk.

The eccentricity of a building can occur in one direction and two directions, depending on the configuration and structure of the building. Variations in the direction of eccentricity in the building will affect the behavior of floor rotation of the building and hence the effects can also vary.

As the eccentricity of building, the earthquake action affects also the floor rotation. The earthquake action recordings are affected by many things, such as the geographical location where the soil response is recorded, the nearby seismic source, and the pulse motions. 
Therefore it is important to review how the eccentricity affect the floor rotation of building under the influence of ground motion containing pulse effect.

\section{Modeling Of The System}

The structural system is taken from the study done by (Beyer $\mathrm{K}$ and Bommer $\mathrm{J}$, 2007)which is so-called Beyer's Model. It has the reinforced concrette wall on each side of the building.The building size is $25 \mathrm{~m}$ x $15 \mathrm{~m}$ and the height is $3 \mathrm{~m}$ for each floor (Figure 1). The stereotypical model in the horizontal direction can be assumed by the 2D model (Figure 1b) because the structure has a regularity in the vertical direction. And each lateral retaining wall is modeled with a nonlinear spring (Figure1c). The mass of all floors is equivalent to an effective mass at the effective height of the building (heff $=9.3 \mathrm{~m}$ ).

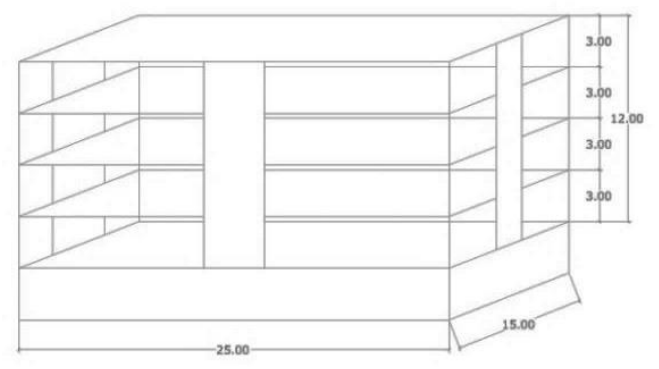

(a)

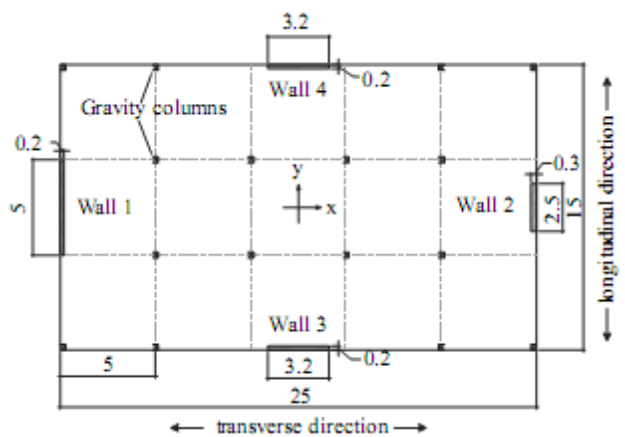

(b) 


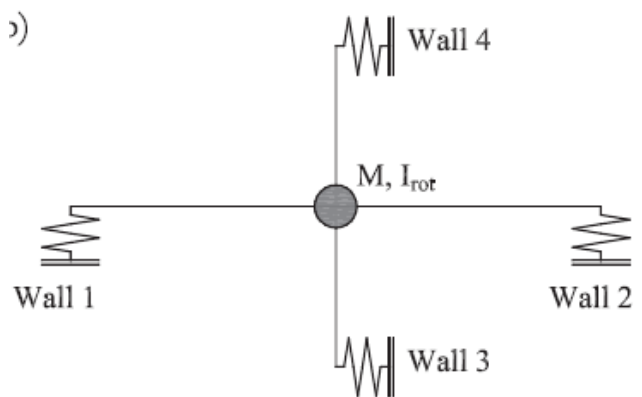

(c)

Fig. 1. (a) Beyer (2007) building model. (b) 2D stereotypical model. (c) Modeling of 2D Stereotypes as nonlinear springs.

Modeling is taken in accordance with study done by (Beyer $\mathrm{K}$ and Bommer $\mathrm{J}$, 2007)However, in the plan model, the size of the shear wall is adjusted in line with the considered eccentricity. As the size of shear wall varies, the building's eccentricity changes as well due to the change of mass and stifness. The overall weight of the floor is considered as Lumped Mass of $9035 \mathrm{kN}$ and located at theeffective height of $9.3 \mathrm{~m}$. The system hasnatural period of $\mathrm{T} 1=0.97 \mathrm{~s}, \mathrm{~T} 2=0.88 \mathrm{~s}$, and $\mathrm{T} 3=0.48 \mathrm{~s}$.For this study the response modification coefficient (R)employed are 3, 4,5 and 6 .

\section{Recording Of Earthquake}

\subsection{Ground Motion}

The earthquake action provides a movement on the ground, which is so-called ground motion. In selecting the ground motion records(Doughlas.J, 2008) explain that the records should be selected from the similar site condition and earthquake mechanism with the condition of the place to be studied. Mostly, the selection should be based on magnitude and distance (and also fault types) from the site of earthquake occurred. The records that matched with the elastic the design spectra are preferred. (Katsanos, E. I., Sextos, A. G., dan Manolis, 2010) explains that the earthquake magnitude and source-to-site distance (in $\mathrm{km}$ ) are the most common parameters.

\subsection{Excitations Contains Pulse Effect}

(Pawirodikromo, 2012) states that the near-fault earthquake have caused massive damage e.g. the Northridge earthquake (1994), the Kobe earthquake (1995), and the Taiwan earthquake (1999). The near-fault ground motion is mainly affected the following points: 1) earthquake mechanism; 2) the direction of fault propagation relative to the site; 3) the possibility of permanent displacement due to fracture. The above mentioned points are then known by quake observers as "rupture directivity" and "fling step". The rupture directivity effect produces the pulse signature in the motion.

\subsection{Selection of Earthquake Recordings}

The simple selection procedure is employed for the ground motion based on magnitude and source-to- site distance (in $\mathrm{km}$ ) are the most common parameters. 
Table 1. Ground Motion Records with Pulse Effect.

\begin{tabular}{|c|c|c|c|c|c|c|c|c|c|}
\hline $\begin{array}{l}\mathrm{N} \\
\mathrm{O}\end{array}$ & $\begin{array}{c}\text { Tp- } \\
\text { Puls } \\
\text { e } \\
\text { Peri } \\
\text { od } \\
(\mathrm{sec})\end{array}$ & $\begin{array}{l}\text { Earthqua } \\
\text { ke Name }\end{array}$ & $\begin{array}{l}\mathrm{Ye} \\
\mathrm{ar}\end{array}$ & $\begin{array}{l}\text { Station } \\
\text { Name }\end{array}$ & $\begin{array}{c}\mathrm{Ma} \\
\mathrm{g} .\end{array}$ & $\begin{array}{l}\text { Mechani } \\
\text { sm }\end{array}$ & $\begin{array}{c}\mathrm{Rjb} \\
(\mathrm{k} \\
\mathrm{m})\end{array}$ & $\begin{array}{c}\text { Rru } \\
\mathrm{p} \\
(\mathrm{k} \\
\mathrm{m})\end{array}$ & $\begin{array}{c}\text { Vs30 } \\
(\mathrm{m} / \mathrm{se} \\
\mathrm{c})\end{array}$ \\
\hline 1 & 1.092 & $\begin{array}{l}\text { Kobe, } \\
\text { Japan }\end{array}$ & 1995 & KJMA & 6.9 & strike slip & 0.94 & 0.96 & 269.14 \\
\hline 2 & 1.372 & $\begin{array}{c}\text { Northridg } \\
\text { e-01 }\end{array}$ & 1994 & $\begin{array}{l}\text { Newhall } \\
\text { - Fire Sta }\end{array}$ & 6.69 & Reverse & 3.16 & 5.92 & 269.14 \\
\hline 3 & 2.828 & $\begin{array}{l}\text { Kobe, } \\
\text { Japan }\end{array}$ & 1995 & $\begin{array}{c}\text { Port } \\
\text { Island (0 } \\
\mathrm{m})\end{array}$ & 6.9 & strike slip & 3.31 & 3.31 & 370.52 \\
\hline 4 & 3.528 & $\begin{array}{c}\text { Northridg } \\
\text { e-01 }\end{array}$ & 1994 & $\begin{array}{l}\text { Sylmar - } \\
\text { Converte } \\
\text { r Sta East }\end{array}$ & 6.69 & Reverse & 0 & 5.19 & 370.52 \\
\hline 5 & 5.341 & $\begin{array}{l}\text { Chi-Chi, } \\
\text { Taiwan }\end{array}$ & 1999 & CHY024 & 7.62 & $\begin{array}{l}\text { Reverse } \\
\text { Oblique }\end{array}$ & 9.62 & 9.62 & 427.73 \\
\hline 6 & 7.791 & $\begin{array}{c}\text { Kocaeli, } \\
\text { Turkey }\end{array}$ & 1999 & Arcelik & 7.51 & strike slip & $\begin{array}{c}10.5 \\
6 \\
\end{array}$ & $\begin{array}{c}13.4 \\
9 \\
\end{array}$ & 353.63 \\
\hline 7 & 6.265 & $\begin{array}{c}\text { Imperial } \\
\text { Valley-06 }\end{array}$ & 1979 & $\begin{array}{l}\text { El Centro } \\
\text { Different } \\
\text { ial Array }\end{array}$ & 6.53 & strike slip & 5.09 & 5.09 & 202.26 \\
\hline 8 & 6.265 & $\begin{array}{l}\text { Imperial } \\
\text { Valley- }\end{array}$ & 1985 & $\begin{array}{l}\text { El Centro } \\
\text { Different } \\
\text { ial Array }\end{array}$ & 5.12 & strike slip & 6.01 & 6.01 & 282.5 \\
\hline 9 & 9.128 & Landers & 1992 & Barstow & 7.28 & strike slip & $\begin{array}{c}34.8 \\
6\end{array}$ & $\begin{array}{c}34.8 \\
6\end{array}$ & 370.08 \\
\hline 10 & $\begin{array}{c}6.18 \\
8 \\
\end{array}$ & $\begin{array}{c}\text { Tabas, } \\
\text { Iran } \\
\end{array}$ & $\begin{array}{c}197 \\
8 \\
\end{array}$ & Tabas & $\begin{array}{c}7.3 \\
5 \\
\end{array}$ & Reverse & $\begin{array}{c}1.7 \\
9 \\
\end{array}$ & $\begin{array}{c}2.0 \\
5 \\
\end{array}$ & $\begin{array}{c}766.7 \\
7 \\
\end{array}$ \\
\hline
\end{tabular}

\section{Details Of Parametric Studies}

\subsection{Eccentricity of The System}

This research has used three eccentricities, which is calculated based on the centre of second moment of inertia of the wall system. Table 2 shows the parameter of the wall system, which indicatesthatthe stiffness of the structure in the state of symmetry in the $\mathrm{x}$-axis.

Table 2. The calculation results for Eccentricity 1 (CR1).

\begin{tabular}{cccc}
\hline Nama Wall & Size & $\mathrm{Ix}\left(\mathrm{m}^{4}\right)$ & $\mathrm{Iy}\left(\mathrm{m}^{4}\right)$ \\
\hline Wall 1 & $4,6 \times 0,2$ & 1,622 & 0,003 \\
\hline Wall 2 & $3,0 \times 0,3$ & 0,673 & 0,007 \\
\hline Wall 3 & $6,0 \times 0,2$ & 3,600 & 0,004 \\
\hline Wall 4 & $6,0 \times 0,2$ & 3,600 & 0,004 \\
\hline
\end{tabular}


So it can be concluded thus there will be no eccentricity to the $\mathrm{x}$-axis. In the $\mathrm{y}$-axis, the stiffness of the asymmetric structure gives an eccentricity of as follows:

$e_{y}=\frac{(0,673 \times 12,5)-(1,622 \times 12,5)}{1,622+0,673+3,600+3,600}$

$e_{y}=-1,250 m$

The negative sign indicates the Eccentricity 1 of $1,250 \mathrm{~m}$ is to the left of the $y$-axis of the center of mass.

Eccentricity 2 and Eccentricity 3 are calculated in the same way as Eccentricity 1 . These results are listed in Table 3.These eccentricities are illustrated in Figure 2.

Table 3. The calculation results for Eccentricity 2 (CR2).

\begin{tabular}{cccc}
\hline Walls & Size & $\mathrm{Ix}\left(\mathrm{m}^{4}\right)$ & $\mathrm{Iy}\left(\mathrm{m}^{4}\right)$ \\
\hline \multicolumn{4}{c}{ Eccentricity 2} \\
\hline Wall 1 & $5,0 \times 0,2$ & 2,083 & 0,003 \\
\hline Wall 2 & $2,5 \times 0,3$ & 0,391 & 0,006 \\
\hline Wall 3 & $6,0 \times 0,2$ & 3,600 & 0,004 \\
\hline Wall 4 & $6,0 \times 0,2$ & 3,600 & 0,004 \\
\hline \multicolumn{4}{c}{ Eccentricity 3 } \\
\hline Wall 1 & $5,26 \times 0,24$ & 2,895 & 0,006 \\
\hline Wall 2 & $2,0 \times 0,2$ & 0,133 & 0,001 \\
\hline Wall 3 & $6,0 \times 0,2$ & 3,600 & 0,004 \\
\hline Wall 4 & $6,0 \times 0,2$ & 3,600 & 0,004 \\
\hline
\end{tabular}

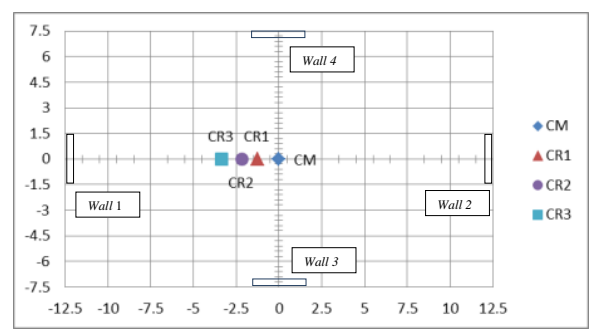

Fig. 2. The pattern of eccentricity of stiffness.

\subsection{Designed Spectrum}

The site of the structural system is assumed to be built in Banda Aceh, which is known as one of the high seismic area in Indonesia. According to SNI 1726-2012, Banda Aceh has the parameter $\mathrm{Ss}=2.0 \mathrm{~g}$ and $\mathrm{S} 1=0.59 \mathrm{~g}$. The designed spectrum is used to scale the selected ground motion based on the spectra value at the same period with the natural period of the building. 


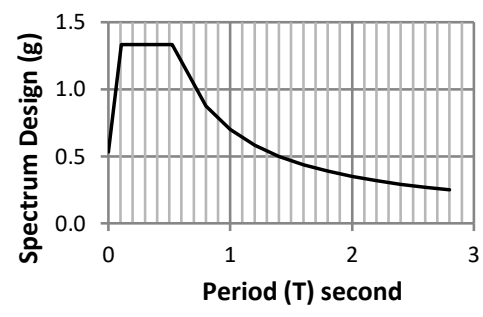

Fig. 3. Designed Spectrum for Banda Aceh (Medium Soil)

\subsection{Base Shear Design (V)}

The base shear design (V) is calculated based on SNI 03-1726-2012.It is produced the results listed in Table 4 . The base shear force is used to calculate the hinge properties of the walls of system.

Table 4: Base Shear design (V)

\begin{tabular}{|c|c|c|}
\hline Eccentricity & $\mathrm{R}$ & $\mathrm{V}(\mathrm{KN})$ \\
\hline \multirow[t]{4}{*}{ Eccentricity 1} & 3 & 2877 \\
\hline & 4 & 2158 \\
\hline & 5 & 1726 \\
\hline & 6 & 1439 \\
\hline \multirow[t]{4}{*}{ Eccentricity 2} & 3 & 2685 \\
\hline & 4 & 2014 \\
\hline & 5 & 1611 \\
\hline & 6 & 1342 \\
\hline \multirow[t]{4}{*}{ Eccentricity 3} & 3 & 2435 \\
\hline & 4 & 1826 \\
\hline & 5 & 1461 \\
\hline & 6 & 1218 \\
\hline
\end{tabular}

\subsection{Nonlinear Inelastic Analysis}

The structural analysis for the system is conducted using the linear elastic and nonlinear inelastic analysis by employing Ruaumoko program (Carr, 2007) as the tool. More than hundred simulations are done with time history analysis to produce the deformation of the floor.

\section{Results And Discussion}

The results are taken from 150 simulations, which is involving 15 building models and 10 ground motions. The overall model of the building is influenced by the parameter of Eccentricity of the building and the Response Modification Factor (R). The building model has 3 variations of eccentricity. The three models of eccentricity of this building have different periods of natural buildings. This happens because of differences in the rigidity of the building. The natural period $(\mathrm{T})$ of the building greatly influences the building response to 
earthquake forces. The analysis shows the difference in deformation of floor rotation in each building.

\subsection{Elastic System}

The floor elastic deformation on the rigid side of the building with eccentricity variation 1 is found to be $0.058 \mathrm{~m}$, whereas the deformation is of $0.120 \mathrm{~m}$ on the flexible side of the building. For the Eccentricity 2, the elastic deformation on the rigid side of the building is reached of $0.065 \mathrm{~m}$, whereas on the flexible side of the buildingis of $0.150 \mathrm{~m}$. The elastic deformation of the floor on the rigid side of the building with Eccentricity 3 is found to be $0.072 \mathrm{~m}$, whereas $0.176 \mathrm{~m}$ is found on the flexible side.

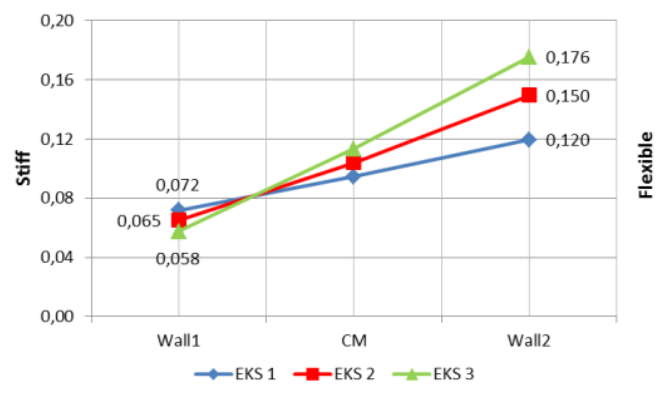

Fig. 4. Elastic deformation of floor

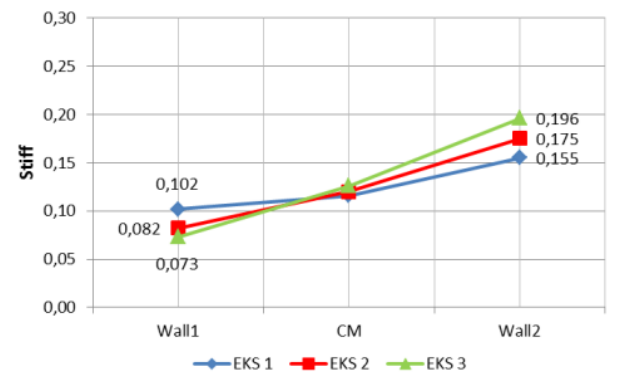

(a)

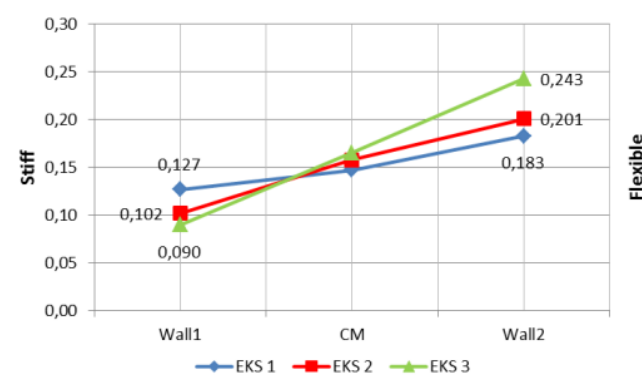

(c)

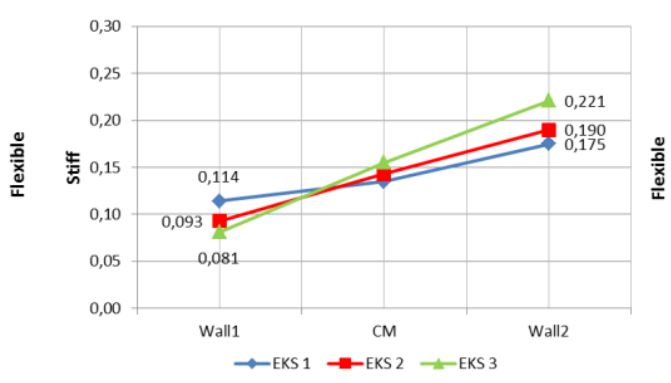

(b)

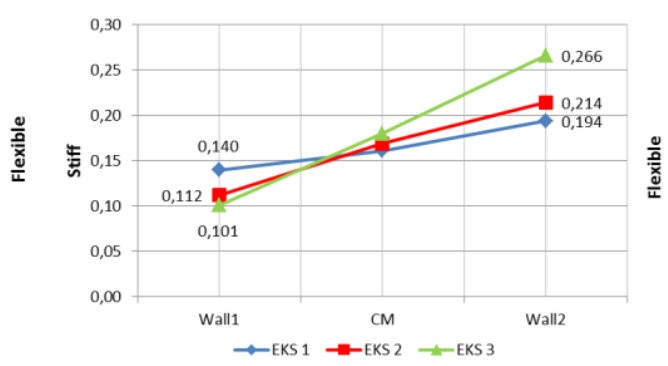

(d)

Fig. 5. Deformation at the floor of the building for the inelastic system (a) System with $R=3$, (b) system with $\mathrm{R}=4$ (c) systems with $\mathrm{R}=5$, (d) Deformation with Value $\mathrm{R}=6$. 


\subsection{Inelastic System}

On the rigid side of the building, the inelastic deformations generated by the seismic ground motions are relatively smaller than the flexible side of the building. Overall, the floor deformation pattern as the result of the inelastic analysis are depicted in Figure 5. The system with Eccentricity 1 produces the deformation on the rigid side of $0.140 \mathrm{~m}$, whereas deformation of $0.194 \mathrm{~m}$ occurs on the flexible building side. For Eccentricity 2 , the inelastic deformation occurred on the rigid side of the building is of $0.112 \mathrm{~m}$, whereas on the flexible side of the building is of $0.214 \mathrm{~m}$. The inelastic deformation of the floor occurred on the rigid side of the building of Eccentricity 3 is of $0.101 \mathrm{~m}$, whereas on the flexible building side is $0.266 \mathrm{~m}$. The existence of different deformation values that occur due to the pulse in the earthquake is worth to be observed. It is because the pulse in earthquake motion could give a large influence on the deformation of the building.

Figure 6shows the deformation on each side of the system, after normalized to the mass centre of the system. From the results can be seen that the deformation occurred in the two buildings are almost the same, exceptthose affected by larger pulse excitation. This result is significantly more visible when the building has two directions of eccentricity.

Table 5. Differences deformation due to pulse excitations at $\mathrm{R}=6$ with varies Eccentricity.

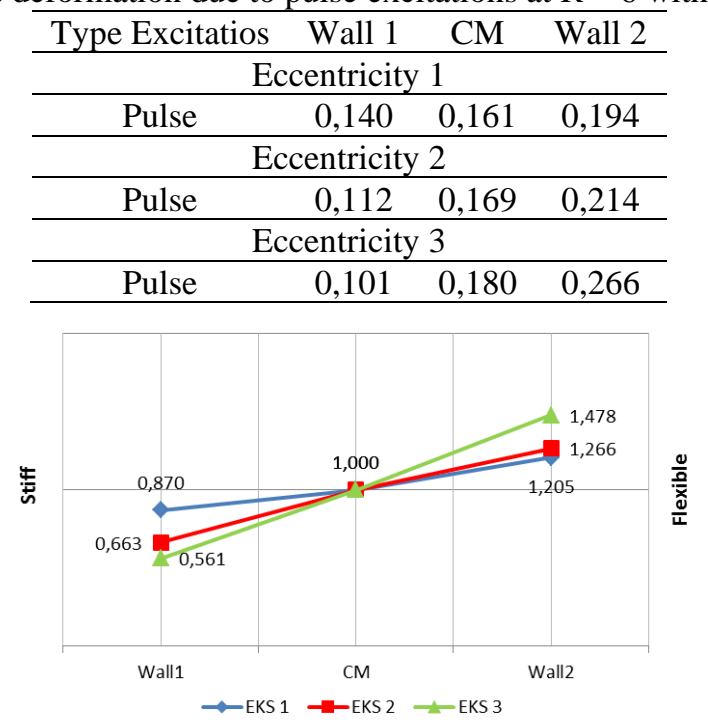

Fig. 6. Normalized deformation of the inelastic system with $R=6$.

\subsection{Elastic vs. Inelastic Building Analysis}

Based on figures presented previously, it is clear that the floor drift that occurs during elastic and inelastic conditions are not the same. And the deformation in inelastic condition is always greater than the elastic condition. The difference in inelastic elasticity value to elastic up to $51 \%$ indicates that the building is still able to survive further than the elastic limit before the building is collapse. 


\section{Conclusions}

This study can conclude the following insights: Inelastic buildings can deform larger than elastic buildings. The maximum elastic deformation has found to be $0.176 \mathrm{~mm}$, whereas the inelastic system produced of $0.226 \mathrm{~mm}$. The difference between the both is reached to $51 \%$, which is indicated that the building is still able to further withstand than the elastic limit before the building is collapsed.

The presence of rigid parts of the building of the other part will affect the location of the center of rigidity thus creating an eccentricity of stiffness. In system with Eccentricity 1, the deformation has shown of 38\% difference, whereas system with Eccentricity 2 and 3has indicated $91 \%$ and $163 \%$ of difference, respectively. These results are the system with $\mathrm{R}=3$.

\section{References}

[1] Beyer K and Bommer J (2007) 'Selection and Scaling of Real Accelerograms for BiDirectional Loading: A Review of Current Practice and Code Provisions', Journal of Earthquake Engineering, vol: 11 (s, pp. 13-45. doi: 10.1080/13632460701280013.

[2] Doughlas.J, and A. . (2008) 'A survey of techniques for predicting earthquake ground motions for engineering purposes, Surveys in Geophysics.', 29, pp. 187-220. Available at: \%0AA survey of techniques for predicting earthquake ground motions for engineering purposes.

[3] Katsanos, E. I., Sextos, A. G., dan Manolis, G. D. (2010) 'Selection of earthquake ground motion records: A state-of-the-art review.', in Soil Dynamics and Earthquake Engineering 30, pp. 157-169.

[4] Pawirodikromo, W. (2012) Seismologi Teknik dan Rekayasa Kegempaan. Pustaka Pelajar. 